\title{
MENINGKATKAN KEMAMPUAN GURU DALAM MELAKSANAKAN PENELITIAN TINDAKAN KELAS MELALUI TEKNIK WORKSHOP DI SDN 7 TELAGA BIRU DAN SDN 9 TELAGA BIRU KABUPATEN GORONTALO
}

\author{
Imran Tululi \\ Pengawas Sekolah Dasar Dinas Pendidikan Kabupaten Gorontalo
}

\begin{abstract}
The problem examined in this study is whether the ability of teachers to carry out classroom action research in the 7 primary schools of Telaga Biru and the 9 primary schools in Telaga Biru Gorontalo Regency can be improved through workshop techniques? "This study aims to improve the ability of teachers to carry out classroom action research through workshop techniques in the 7 primary schools in Telaga Biru and 9 primary schools in Telaga Biru, Gorontalo District. The method used in this research is descriptive method. The results showed that, 1) the ability of teachers to carry out classroom action research in public elementary schools 7 Telaga Biru and in public elementary schools 9 Telaga Biru had increased after being subjected to action through II cycles, 2) an increase in the teacher's ability to carry out classroom action research was marked with the optimal mastery of the 10 indicators of classroom action research namely a) the ability to identify problems, $b$ ) the ability to formulate problems, $c$ ) the ability to formulate hypotheses, $d$ ) the ability to make research instruments, e) the ability to make plans for action and monitoring, f) the ability to implement actions and observing them, $g$ ) the ability to collaborate with partner teachers in research, $h$ ) the ability to process and interpret data, $i$ ) the ability to make conclusions of research results, and $j$ ) the ability to compile reports on research results.
\end{abstract}

Keywords: Classroom Action Research, Workshop Techniques

\begin{abstract}
Abstrak
Permasalahan yang dikaji dalam penelitian ini adalah apakah kemampuan guru dalam melaksanakan penelitian tindakan kelas di sekolah dasar negeri 7 Telaga Biru dan SDN 9 Telaga Biru Kabupaten Gorontalo dapat ditingkatkan melalui teknik workshop? "Penelitian ini bertujuan untuk meningkatkan kemampuan guru dalam melaksanakan penelitian tindakan kelas melalui teknik workshop di sekolah dasar negeri 7 Telaga Biru dan sekolah dasar negeri 9 Telaga Biru Kabupaten Gorontalo. Metode yang digunakan dalam penelitian ini adalah metode deskriptif. Hasil penelitian menunjukkan bahwa, 1) kemampuan guru dalam melaksanakan penelitian tindakan kelas di sekolah dasar negeri 7 Telaga Biru dan di sekolah dasar negeri 9 Telaga Biru mengalami peningkatan setelah dikenai tindakan melalui II siklus, 2) peningkatan kemampuan guru dalam dalam melaksanakan penelitian tindakan kelas ditandai dengan penguasaan guru secara optimal terhadap 10 indikator penelitian tindakan kelas yaitu a) kemampuan mengidentifikasi masalah, b) kemampuan merumuskan masalah, c) kemampuan merumuskan hipotesis, d) kemampuan membuat instrumen penelitian, e) kemampuan membuat rencana tindakan dan pemantauan, f) kemampuan melaksanakan tindakan dan mengamatinya, g) kemampuan berkolaborasi dengan guru mitra dalam penelitian, h) kemampuan mengolah dan menafsirkan data, i) kemampuan membuat simpulan hasil penelitian, dan j) kemampuan menyusun laporan hasil penelitian.
\end{abstract}

Kata Kunci: Penelitian Tindakan Kelas, Teknik Workshop 


\section{PENDAHULUAN}

Peningkatan profesionalisme guru merupakan bagian dari upaya untuk mengembangkan kompetensi guru secara optimal. Profesi guru adalah profesi yang berkembang terus menerus dan berkesinambungan. Adanya persyaratan profesionalisme guru ini maka perlu adanya paradigma baru untuk melahirkan profil guru Indonesia yang benar-benar profesional. Guru yang profesional harus memiliki kepribadian yang matang dan berkembang, dengan penguasaan ilmu yang kuat dan keterampilan untuk membangkitkan peserta didik kepada sains dan teknologi dan melakukan pengembangan profesi secara berkesinambungan penelitian tindakan kelas.

Peningkatan kemampuan guru dalam melaksanakan penelitian tindakan kelas merupakan bagian dari kemampuan yang perlu dikuasai guru untuk mencapai profesionalitas dalam bekerja. Kemampuan melaksanakan penelitian tindakan kelas perlu dilakukan sebagai upaya guru untuk lebih mamahami dan mengenal masalah yang dihadapinya dalam pembelajaran. Upaya yang dilakukan guru dalam melaksanakan penelitian tindakan kelas sebagai upaya untuk mencarikan solusi atas permasalahan yang dihadapinya melalui pembelajaran melalui penelitian tindakan yang dilakukannya.

Dalam konteks ini melalui penelitian tindakan kelas yang dilakukan guru diharapkan mampu menemukan solusi empirik yang tepat atas permasalahan yang dihadapi dalam pembelajaran. Dengan demikian maka kemampuan guru dalam melakukan penelitian ilmian akan berkembang dengan baik.

Penelitian tindakan kelas yang dilakukan guru dalam pembelajaran akan memberikan dampak terhadap lahirnya produk berupa laporan-laporan PTK yang dapat dijadikan bahan panduan guru untuk meningkatkan mutu pembelajaran. Selain itu hasil-hasil PTK yang dilaporkan dapat menjadi bahan artikel ilmiah atau makalah untuk berbagai kepentingan, antara lain disajikan dalam forum ilmiah dan dimuat di jurnal ilmiah. PTK yang dihasilkan guru juga akan mampu untuk menumbuhkembangkan kebiasaan, budaya, dan atau tradisi meneliti dan menulis artikel ilmiah di kalangan guru. Hal ini telah ikut mendukung profesionalisme dan karir guru.Dalam konteks yang bersamaan diharapkan mampu mewujudkan kerja sama, kaloborasi, dan atau sinergi antarguru dalam satu sekolah atau beberapa sekolah untuk bersama-sama memecahkan masalah pembelajaran dan meningkatkan mutu pembelajaran, serta mampu 
meningkatkan kemampuan guru dalam menjabarkan kurikulum atau program pembelajaran sesuai dengan tuntutan dan konteks lokal, sekolah, dan kelas. Hal ini memperkuat dan relevansi pembelajaran bagi kebutuhan siswa.

Riyanti (2009:12) mengemukakan bahwa melalui penelitian tindakan kelas maka akan mampu memupuk dan meningkatkan keterlibatan, kegairahan, ketertarikan, kenyamanan, dan kesenangan siswa dalam mengikuti proses pembelajaran di kelas yang dilaksanakan guru. Hasil belajar siswa pun dapat meningkatkan, serta dapat mendorong terwujudnya proses pembelajaran yang menarik, menantang, nyaman, menyenangkan, dan melibatkan siswa karena strategi, metode, teknik, dan atau media yang digunakan dalam pembelajaran demikian bervariasi dan dipilih secara sungguh-sungguh.

Kecenderung yang terjadi bahwa sebagian guru kurang memahami cara dalam melakukan penelitian tindakan kelas. Guru kurang mampu mengenali masalah yang dihadapinya dalam pembelajaran. Guru juga kurang mampu melakukan identifikasi terhadap masalah yang dihadapi siswanya, dan tidak mampu memilih strategi yang tepat untuk memecahkan masalah yang dihadapi baik dalam pembelajaran maupun di luar pembelajaran.
Permasalahan lainnya yang dihadapi guru adalah rendahnya kemampuan guru untuk membuat laporan hasil penelitian tindakan kelas. Guru mengalami kesulitan dalam memformulasikan kalimat dalam membuat laporan hasil penelitian tindakan kelas. Hal ini yang menyebabkan hasil penelitian tindakan kelas yang dibuat guru tidak dapat di susun dalam bentuk laporan hasil penelitian tindakan kelas.

Kondisi rendahnya kemampuan guru dalam melaksanakan penelitian tindakan kelas menjadikanguru pada umumnya tidak dapat melakukan kegiatan penelitian ilmiah sesuai dengan yang diharapkan.Berdasarkan permasalahan penelitian tersebut maka peneliti melakukan kegiatan penelitian untuk meningkatkan kemampuan guru dalam melaksanakan penelitian tindakan kelas. Terkait dengan hal tersebut peneliti menggunakan teknik kegiatan workshopuntuk meningkatkan kemampuan guru dalam melaksanakan penelitian tindakan kelas.

\section{KAJIAN TEORI}

\section{Penelitian Tindakan Kelas (PTK)}

Suharsimi (2012) menjelaskan PTK melalui gabungan definisi dari tiga kata yaitu "Penelitian" + "Tindakan" + "Kelas". Makna setiap kata tersebut adalah sebagai 
berikut. Penelitian; kegiatan mencermati suatu obyek dengan menggunakan cara dan metodologi tertentu untuk memperoleh data atau informasi yang bermanfaat dalam memecahkan suatu masalah. Asrori (2010:6) menyatakan bahwa PTK merupakan bentuk penelitian tindakan yang diterapkan dalam aktivitas pembelajaran di kelas. PTK adalah penelitian tindakan yang dilaksanakan di dalam kelas ketika pembelajaran berlangsung. PTK dilakukan dengan tujuan untuk memperbaiki atau meningkatkan kualitas pembelajaran. PTK berfokus pada kelas atau pada proses pembelajaran yang terjadi di dalam kelas. Dari definisi diatas dapat di simpulkan bahwa PTK merupakan suatu kegiatan yang dapat di lakukan oleh guru kapan saja dengan melihat permasalahanpermasalahan yang terjadi pada saat proses pembelajaran.

\section{Workshop}

Hadiyanto (2009:2) mengemukakan bahwa workshop merupakan frasa kata yang berasal dari bahasa Inggris yaitu work (yang memiliki arti kerja ataupun pekerjaan) dan shop (yang memiliki arti toko ataupun tempat menjual sesuatu). Jadi jika diartikan dari frasa kata, workshop dapat diartikan sebagai tempat berkumpulnya para pelaku aktivitas (berkaitan dengan bidang dunia kerja) tertentu yang mana dalam tempat ini, para pelaku melakukan interaksi saling menjual gagasan yang ditujukan untuk memecahkan suatu permasalahan tertentu. Farhan (2010:3) menjelaskan bahwa jika diartikan secara lengkap, maka workshop merupakan sebuah kegiatan yang sengaja diadakan sebagai tempat berkumpulnya orang-orang yang berasal dari latar belakang serumpun untuk memecahkan suatu permasalahan tertentu dengan jalan berdiskusi ataupun saling memberikan pendapat antar satu anggota dengan anggota lainnya. Dari kedua teori diatas disimpulkan bahwa worksop merupakan kegiatan yang dilakukan oleh lembaga atau instansi yang berfungsi sebagai wahana untuk saling bertukat pendapat dan saran.

\section{METODE PENELITIAN}

Metode yang digunakan dalam penelitian ini adalah metode deskriptif. Dengan teknik pengumpulan data observasi dan dokumentasi. Teknik analisis data yang digunakan adalah analisis prosentase. Penelitian dilaksanakan dalam dua siklus, tiap siklus terdiri dari tahap awal, tahap pelaksanaan tindakan, tahap pemantauan dan evaluasi. Dengan menggunakan dua variabel yaitu variabel input, variabel proses dan variabel output. Penelitian ini di lakukan dengan menggunakan dua siklus. 
HASIL DAN PEMBAHASAN

Kemampuan guru dalam melaksanakan penelitian tindakan kelas di SDN 7 Telaga Biru sangat rendah, hal ini ditunjukkan dengan rendahnya kemampuan guru dalam menguasai komponen penelitian tindakan kelas. Dari 10 komponen utama yang diharapkan dapat dikuasai guru hanya 3 komponen $30 \%$ yang dapat dikuasai guru dengan kategori cukup), sedangkan $30 \%$ dengan 3 komponen kategori kurang dan $40 \%$ kategori tidak baik dengan 4 komponen yang di kuasai guru, melihat hal ini ternyata di SDN 7 Telaga Biru kegiatan guru dalam menguasai komponen PTK sangat kurang baik dan perlu bimbingan sehingga pelaksanaan workshop sangat di perlukan untuk meningkatkan kemampuan guru dalam melaksanakan PTK tersebut.

Tabel 1.

Kemampuan Guru dalam Melaksanakan penelitian tindakan kelas Tahap Pengamatan Awal di SDN 7 Telaga Biru

\begin{tabular}{|c|c|c|c|c|}
\hline Kriteria Aspek yang dinilai & Baik & Cukup & Kurang & Tidak Baik \\
\hline Kemampuan mengidentifikasi masalah & - & $\sqrt{ }$ & - & - \\
\hline Kemampuan merumuskan masalah & - & $\sqrt{ }$ & - & - \\
\hline Kemampuan merumuskan hipotesis & - & $\sqrt{ }$ & & - \\
\hline Kemampuan membuat instrumen penelitian & - & - & - & $\sqrt{ }$ \\
\hline Kemampuan membuat rencana tindakan dan & - & - & $\sqrt{ }$ & - \\
\hline Kemampuan melaksanakan tindakan dan & - & - & $\sqrt{ }$ & - \\
\hline Kemampuan berkolaborasi dengan guru & - & - & $\sqrt{ }$ & - \\
\hline $\begin{array}{l}\text { mira dadam nenewrian } \\
\text { Kemampuan mengolah dan menafsirkan }\end{array}$ & - & - & - & $\sqrt{ }$ \\
\hline Kemampuan membuat simpulan hasil & - & - & - & $\sqrt{ }$ \\
\hline Kemampuan menyusun laporan hasil & - & - & - & $\sqrt{ }$ \\
\hline Jumlah & 0 & 3 & 3 & 4 \\
\hline$\%$ & 0 & $30 \%$ & $30 \%$ & $40 \%$ \\
\hline
\end{tabular}

Selanjutnya penelitian tindakan kelas yang di SDN 9 Telaga Biru diperoleh hasil sebagai berikut: Dari 10 komponen yang termasuk pada kategori cukup sebanyak 3 komponen atau 30\%, kategori kurang 2 komponen atau $20 \%$ dan kategori kurang baik sebanyak 5 komponen atau $50 \%$. Untuk lebih jelasnya dapat dilihat pada tabel berikut ini: 
Tabel 2.

Kemampuan Guru dalam Melaksanakan penelitian tindakan kelas

Tahap Pengamatan Awal di SDN 9 Telaga Biru

\begin{tabular}{|l|c|c|c|c|}
\hline \multicolumn{1}{|c|}{ Kriteria Aspek yang dinilai } & Baik & Cukup & Kurang & Tidak Baik \\
\hline Kemampuan mengidentifikasi masalah & - & $\sqrt{ }$ & - & - \\
\hline Kemampuan merumuskan masalah & - & $\sqrt{ }$ & - & - \\
\hline Kemampuan merumuskan hipotesis & - & $\sqrt{ }$ & & - \\
\hline Kemampuan membuat instrumen penelitian & - & - & - & $\sqrt{ }$ \\
\hline $\begin{array}{l}\text { Kemampuan membuat rencana tindakan dan } \\
\text { pemantauan }\end{array}$ & - & - & $\sqrt{ }$ & - \\
\hline $\begin{array}{l}\text { Kemampuan melaksanakan tindakan dan } \\
\text { mengamatinya }\end{array}$ & - & - & $\sqrt{ }$ & - \\
\hline $\begin{array}{l}\text { Kemampuan berkolaborasi dengan guru } \\
\text { mitra dalam penelitian }\end{array}$ & - & - & - & $\sqrt{ }$ \\
\hline Kemampuan mengolah dan menafsirkan & - & - & - & $\sqrt{ }$ \\
\hline $\begin{array}{l}\text { Kemampuan membuat simpulan hasil } \\
\text { penelitian }\end{array}$ & - & - & - & $\sqrt{ }$ \\
\hline Kemampuan menyusun laporan hasil & - & - & - & $\sqrt{ }$ \\
\hline \multicolumn{1}{|c|}{ Jumlah } & 0 & 3 & 3 & 4 \\
\hline
\end{tabular}

Berdasarkan temuan dari kegiatan pengamatan awal di SDN 7 Telaga Biru dan guru di SDN 9 Telaga Biru Kabupaten Gorontalo maka perlu ditingkatkan kemampuan guru dalam melaksanakan penelitian tindakan kelas sesuai dengan masalah yang dihadapi mereka dalam kelas. Terkait dengan hal ini maka di lanjutkan kegiatan siklus I dengan fokus pada upaya perbaikan dan peningkatan kemampuan guru dalam melaksanakan penelitian tindakan kelas.
Pelaksanaan kegiatan untuk meningkatkan kemampuan guru dalam melaksanakan penelitian tindakan kelas ini dilakukan dengan menggunakan workshop.

Adapun hasil dari siklus I di SDN 7

Telaga Biru setelah dilakukan kegiatan workshop mengalami peningkatan dari observasi awal sebelumnya. 6 komponen termasuk pada kategori baik, 4 komponen kategori cukup. Sedangkan kategori kurang dan tidak baik nol. Lebih jelasnya pada tebel berikut. 
Tabel 3.

Kemampuan Guru dalam Melaksanakan penelitian tindakan kelas

Tahap Siklus I di SDN 7 Telaga Biru

\begin{tabular}{|c|c|c|c|c|}
\hline Kriteria Aspek yang dinilai & Baik & Cukup & Kurang & Tidak Baik \\
\hline Kemampuan mengidentifikasi masalah & $\sqrt{ }$ & - & - & - \\
\hline Kemampuan merumuskan masalah & $\sqrt{ }$ & - & - & - \\
\hline Kemampuan merumuskan hipotesis & $\sqrt{ }$ & - & & - \\
\hline Kemampuan membuat instrumen penelitian & $\sqrt{ }$ & - & & - \\
\hline Kemampuan membuat rencana tindakan dan & $\sqrt{ }$ & - & - & - \\
\hline Kemampuan melaksanakan tindakan dan & $\sqrt{ }$ & - & - & - \\
\hline Kemampuan berkolaborasi dengan guru & - & $\sqrt{ }$ & - & - \\
\hline $\begin{array}{l}\text { mitra dalam nenelitian } \\
\text { Kemampuan mengolah dan menafsirkan }\end{array}$ & - & $\sqrt{ }$ & - & - \\
\hline Kemampuan membuat simpulan hasil & - & $\sqrt{ }$ & - & - \\
\hline $\begin{array}{l}\text { nenelitian } \\
\text { Kemampuan menyusun laporan hasil }\end{array}$ & - & $\sqrt{ }$ & - & - \\
\hline Jumlah & 6 & 4 & 0 & 0 \\
\hline$\%$ & $60 \%$ & $40 \%$ & 0 & 0 \\
\hline
\end{tabular}

Hasil dari siklus I di SDN 9 Telaga

Biru setelah dilakukan kegiatan workshop mengalami peningkatan dari observasi awal sebelumnya. 7 komponen termasuk pada kategori baik, 3 komponen kategori cukup. Sedangkan kategori kurang dan tidak baik nol. Lebih jelasnya pada tebel berikut.

Tabel 4.

Kemampuan Guru dalam Melaksanakan Penelitian Tindakan Kelas

Siklus I di SDN 9 Telaga Biru

\begin{tabular}{|c|c|c|c|c|}
\hline Kriteria Aspek yang dinilai & Baik & Cukup & Kurang & Tidak Baik \\
\hline Kemampuan mengidentifikasi masalah & $\sqrt{ }$ & - & - & - \\
\hline Kemampuan merumuskan masalah & $\sqrt{ }$ & - & - & - \\
\hline Kemampuan merumuskan hipotesis & $\sqrt{ }$ & - & - & - \\
\hline Kemampuan membuat instrumen penelitian & $\sqrt{ }$ & - & - & - \\
\hline $\begin{array}{l}\text { Kemampuan membuat rencana tindakan dan } \\
\text { pemantauan }\end{array}$ & $\sqrt{ }$ & - & - & - \\
\hline Kemampuan melaksanakan tindakan dan mengamati & $\sqrt{ }$ & - & - & - \\
\hline Kemampuan berkolaborasi dengan guru mitra & $\sqrt{ }$ & - & - & - \\
\hline Kemampuan mengolah dan menafsirkan data & - & $\sqrt{ }$ & - & - \\
\hline Kemampuan membuat simpulan hasil penelitian & - & $\sqrt{ }$ & - & - \\
\hline Kemampuan menyusun laporan hasil penelitian & - & $\sqrt{ }$ & - & - \\
\hline Jumlah & 7 & 3 & 0 & 0 \\
\hline$\%$ & $70 \%$ & $30 \%$ & 0 & 0 \\
\hline
\end{tabular}


Kemampuan guru di SDN 7 Telaga Biru dalam melaksanakan penelitian tindakan kelas setelah dilakukan kegiatan workshop pada siklus II mengalami peningkatan dari siklus I sebelumnya. Dari 10 komponen kesemuannya terpenuhi dengan baik sehingga komponen cukup, kurang dan tidak baik hasilnya nol. Hal ini menunjukkan bahwa kemampuan guru dalam memyusun penelitian tindakan kelas sudah terlaksana dengan baik. Lebih jelasnya pada tebel berikut.

Tabel 5.

Kemampuan Guru dalam Melaksanakan Penelitian Tindakan Kelas

Siklus II di SDN 7 Telaga Biru

\begin{tabular}{|l|c|c|c|c|}
\hline \multicolumn{1}{|c|}{ Kriteria Aspek yang dinilai } & Baik & Cukup & Kurang & $\begin{array}{c}\text { Tidak } \\
\text { Baik }\end{array}$ \\
\hline Kemampuan mengidentifikasi masalah & $\sqrt{ }$ & - & - & - \\
\hline Kemampuan merumuskan masalah & $\sqrt{ }$ & - & - & - \\
\hline Kemampuan merumuskan hipotesis & $\sqrt{ }$ & - & - & - \\
\hline Kemampuan membuat instrumen & $\sqrt{ }$ & - & - & - \\
\hline $\begin{array}{l}\text { Kemampuan membuat rencana tindakan } \\
\text { dan pemantauan }\end{array}$ & $\sqrt{ }$ & - & - & - \\
\hline $\begin{array}{l}\text { Kemampuan melaksanakan tindakan dan } \\
\text { mengamatinya }\end{array}$ & $\sqrt{ }$ & - & - & - \\
\hline $\begin{array}{l}\text { Kemampuan berkolaborasi dengan guru } \\
\text { mitra dalam penelitian }\end{array}$ & $\sqrt{ }$ & - & - & - \\
\hline Kemampuan mengolah dan menafsirkan & $\sqrt{ }$ & - & - & - \\
\hline $\begin{array}{l}\text { Kemampuan membuat simpulan hasil } \\
\text { penelitian }\end{array}$ & $\sqrt{ }$ & - & - & - \\
\hline $\begin{array}{l}\text { Kemampuan menyusun laporan hasil } \\
\text { penelitian }\end{array}$ & $\sqrt{ }$ & - & - & - \\
\hline \multicolumn{1}{|c|}{$\%$} & $100 \%$ & 0 & 0 & 0 \\
\hline
\end{tabular}

Selanjutnya dari hasil pengamatan diperoleh persentase capaian kemampuan guru di SDN 9 Telaga Biru dalam melaksanakan penelitian tindakan kelas siklus II ditampilkan dalam tabel berikut: 
Tabel 6.

Kemampuan Guru dalam Melaksanakan penelitian tindakan kelas

Siklus II di SDN 9 Telaga Biru

\begin{tabular}{|l|c|c|c|c|}
\hline \multicolumn{1}{|c|}{ Kriteria Aspek yang dinilai } & Baik & Cukup & Kurang & Tidak Baik \\
\hline Kemampuan mengidentifikasi masalah & $\sqrt{ }$ & - & - & - \\
\hline Kemampuan merumuskan masalah & $\sqrt{ }$ & - & - & - \\
\hline Kemampuan merumuskan hipotesis & $\sqrt{ }$ & - & - & - \\
\hline Kemampuan membuat instrumen penelitian & $\sqrt{ }$ & - & - & - \\
\hline $\begin{array}{l}\text { Kemampuan membuat rencana tindakan dan } \\
\text { pemantauan }\end{array}$ & $\sqrt{ }$ & - & - & - \\
\hline $\begin{array}{l}\text { Kemampuan melaksanakan tindakan dan } \\
\text { mengamatinya }\end{array}$ & $\sqrt{ }$ & - & - & - \\
\hline $\begin{array}{l}\text { Kemampuan berkolaborasi dengan guru } \\
\text { mitra dalam penelitian }\end{array}$ & $\sqrt{ }$ & - & - & - \\
\hline Kemampuan mengolah dan menafsirkan & $\sqrt{ }$ & - & - & - \\
\hline $\begin{array}{l}\text { Kemampuan membuat simpulan hasil } \\
\text { penelitian }\end{array}$ & $\sqrt{ }$ & - & - & - \\
\hline Kemampuan menyusun laporan hasil & $\sqrt{ }$ & - & & - \\
\hline \multicolumn{1}{|c|}{$\%$} & $100 \%$ & 0 & 0 & 0 \\
\hline
\end{tabular}

Kemampuan guru di SDN 9

Telaga Biru dalam melaksanakan penelitian tindakan kelas setelah dilakukan kegiatan workshop pada siklus II mengalami peningkatan dari siklus I sebelumnya. Dari 10 komponen kesemuannya terpenuhi dengan baik sehingga komponen cukup, kurang dan tidak baik hasilnya nol. Berdasarkan hasil penelitian tindakan sekolah yang dilaksanakan selama 2 siklus di SDN 7 Telaga Biru dan SDN 9 Telaga Biru Kabupaten Gorontalo, diperoleh data hasil penelitian terkait peningkatan kemampuan guru dalam melaksanakan penelitian tindakan kelas. Dari kegiatan siklus I di
SDN 7 Telaga Biru dan di SDN 9 Telaga Biru menunjukkan bahwa kemampuan guru dalam melaksanakan penelitian tindakan kelas mengalami peningkatan dari hasil pengamatan sebelumnya. Dalam konteks ini guru telah dapat melaksanakan penelitian tindakan kelas setelah kegiatan workshop dilakukan. Sedangkan pada siklus II keseluruhan komponen yang menjadi kriteria utama penilaian kemampuan guru dalam melakukan penelitian tindakan kelas keseluruhannya tercapai setelah di laksanakannya kegiatan workshop. 


\section{KESIMPULAN}

Berdasarkan deskripsi hasil penelitian dan pembahasan, dapat disimpulkan bahwa kemampuan guru dalammelaksanakan penelitian tindakan kelas di SDN 7 Telaga Biru dan di SDN 9 Telaga Biru mengalami peningkatan setelah dilaksanakan kegiatan workshop melalui 2 tahapan siklus. Peningkatan kemampuan guru dalam melaksanakan penelitian tindakan kelas ditandai dengan penguasaan guru secara optimal terhadap 10 komponen penelitian tindakan kelas yaitu a) kemampuan mengidentifikasi masalah, b) kemampuan merumuskan masalah, c) kemampuan merumuskan hipotesis, d) kemampuan membuat instrumen penelitian, e) kemampuan membuat rencana tindakan dan pemantauan, f) kemampuan melaksanakan tindakan dan mengamatinya, g) kemampuan berkolaborasi dengan guru mitra dalam penelitian, h) kemampuan mengolah dan menafsirkan data, i) kemampuan membuat simpulan hasil penelitian, dan j) kemampuan menyusun laporan hasil penelitian

\section{DAFTAR PUSTAKA}

Ahmad. (2010). Workshop. Tersedia di http.://gurupembaharu.com/home/ ? $\mathrm{p}=4388$. (Download) 2 Pebruari 2010
Suharsimi, A. (2012), Penelitian Tindakan Kelas.Jakarta : Rineka Cipta

Asrori. (2010). Penelitian Tindakan Kelas. Bandung: Alfabetha

Depdiknas, (1998). Manajemen Sekolah. Jakarta : Direktorat Jenderal Pendidikan Dasar dan Menengah

Indrayanto. (2010). Workshop. (Online). Tersedia dihttp://id.shvoong.com/ social-sciences/education/2025213supervisi-akademik/. (Download, 2 Pebruari 2010)

Indrayanto. (2010). Prinsip-prinsip Workshop. Tersedia di http://id.shvoong. com/socialsciences/education/2025215prinsip-prinsip-supervisiakademik/.(Download, 2 Pebruari 2010)

Kemmis (1988). Class Room Action Research. New York.inc.Publish

Nurihsan J.A. (2005). Strategi Layanan Workshop. Jakarta: PT Rafika Aditama.

Nurihsan J.A. \& Syamsu. (2010). Landasan Workshop. Bandung: Program Pasca Sarjana Universitas Pendidikan Indonesia dan PT Remaja Rosda Karya

Moleong. (2001). Metodologi Penelitian Kualitatif. Cet XIII. Bandung: Remaja Rosdakarya.

Surya. (1988). Pengantar Bimbingan dan Penyuluhan. Jakarta : UT.

Hamalik.H. 2000. Psikologi Belajar dan Mengajar. Bandung: Sinar Baru Algensindo. 
Prayitno Erman Amti. (1997). Dasardasar Workshop. Jakarta: Depdikbud.

Rustantiningsih.(2010).Peran Guru Kelas Dalam Pelaksanaan Bimbingan Bimbingandi Sekolah Dasar(Online) Tersedia di http://researchengines.com/rustianti 40708 . htm. (Download, 2 Pebruari 2010)

Riyanti. (2009). Panduan Praktis Penyusunan Penelitian Tindakan Kelas. Jakarta: Jurnal

Sardiman. (2001). Interaksi dan Motivasi Belajar-Mengajar. Jakarta: Raja Grafindo Persada.

Sudirman. (2009). Evaluasi Hasil Belajar. Jakarta. Haparan. Masa.

Sudradjat Akhmad. A 2010. Kesulitan Belajar Siswa dan Bimbingan Belajar (Online) Tersedia di http/www.kes.rtti.,com.press.html

Sukayati. (2008). Metode Penelitian Tindakan Kelas. Jakarta: Harapan Ilmu.

Tim Pengembangan MKDK IKIP Semarang. 1990. Workshop Sekolah. Semarang: IKIP Semarang Press. 